VISUAL ANTHROPOLOGY

\title{
Meaning-Making at a Japanese Indigo Plantation
}

\section{CHRISTINEWU}



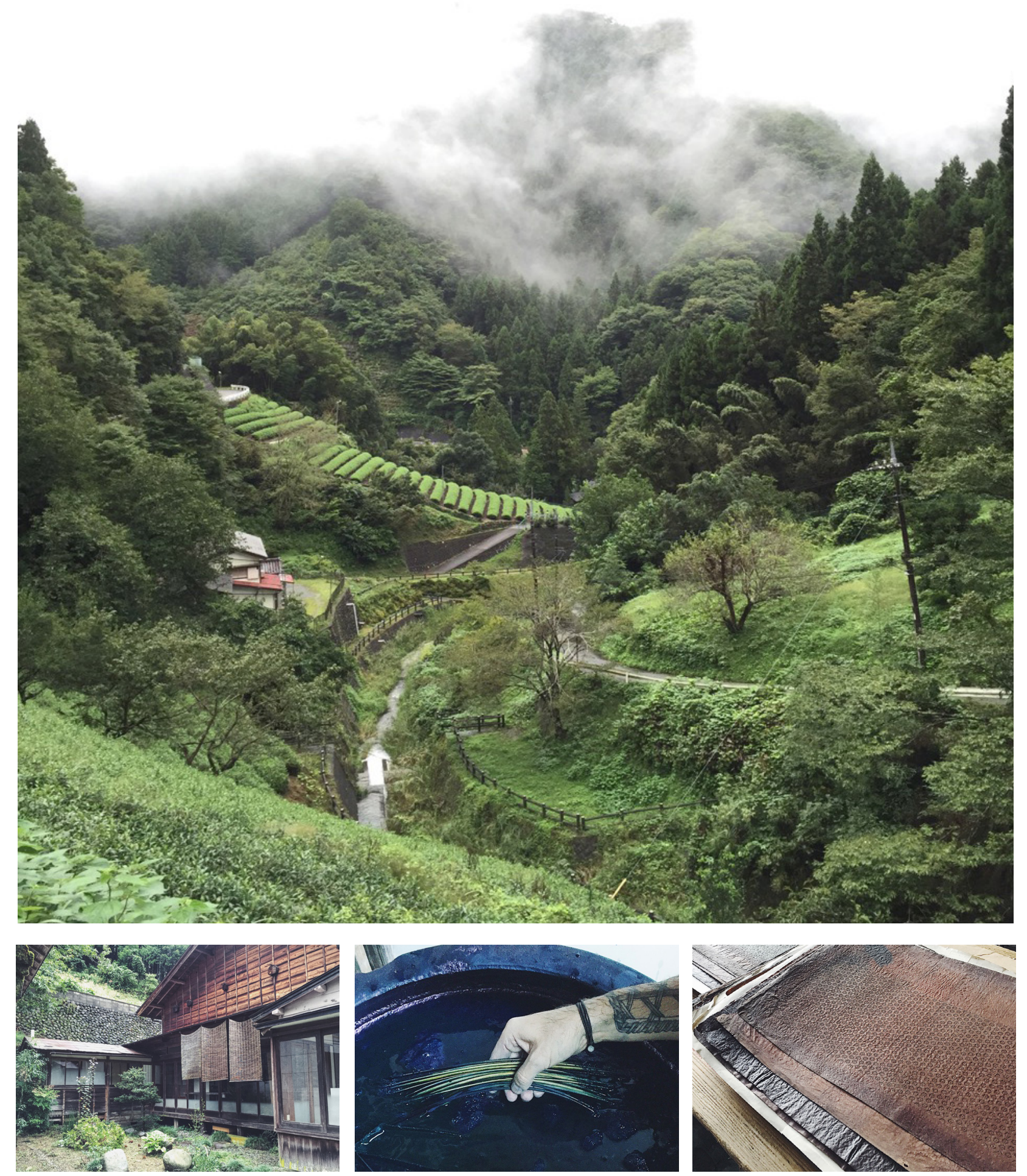

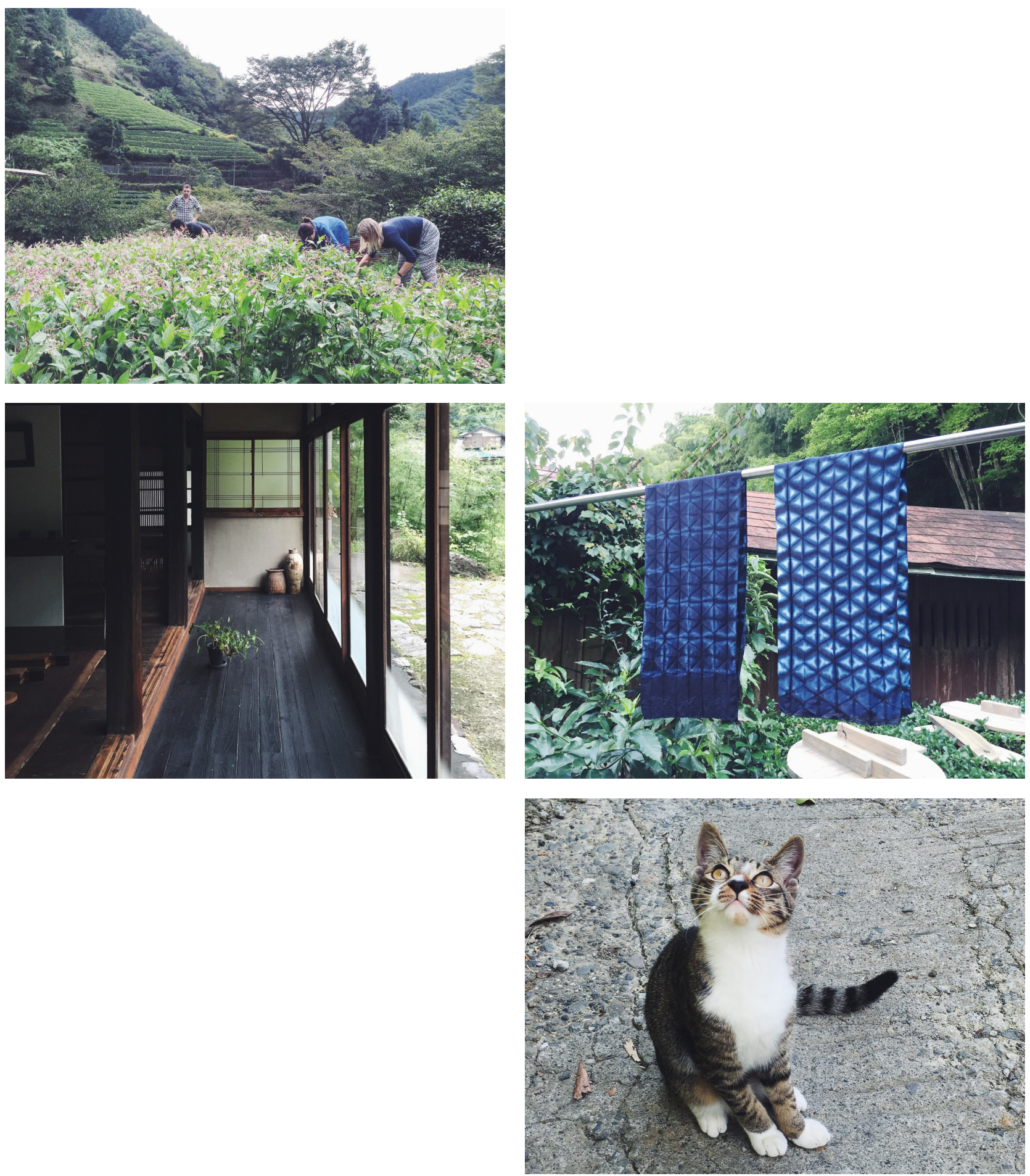


\title{
Meaning-Making at a Japanese Indigo Plantation
}

\author{
CHRISTINE WU
}

Sunlight glinted off of metal handrails as the train sped through the suburbs of western Tokyo. Morning commuters queued impatiently at each station, silently packing into crowded cars like sardines in a can. Tachikawa...Hachioji... each station was another dance of passengers alighting and boarding onto over-packed trains. As the train headed towards its final destination, the landscape thinned, urban buildings giving way to suburban sprawl, and then scattered trees, which became hills dotted with small structures. The passengers dwindled. By the time the train pulled into the terminus at the base of Mount Takao, there were only a handful of elderly riders decked in mountain-climbing gear. I disembarked with the hikers and transferred to a local train, journeying another two stations further west to Fujino Station. There, the hills became mountains. My host, Russell, was waiting with a wave and a halfsmile in his beat-up silver van. A charming, blue-eyed Canadian man in his early 50 s, Russell has been living in Japan for over 30 years and now calls this village his home. A bumpy 20-minute drive took us along winding roads, climbing ever higher over small bridges and through dark mountain tunnels. Windows rolled down, the air changed palpably as we drove deeper into the mountains, asphalt traffic giving way to a fresh green smell of damp earth and cedar mingled with the tart citrus scent of yuzu. The van lurched precariously around a sharp bend in a single-car lane, with a sheer drop on the other side of my passenger window. From the ledge, one could see Mount Fuji framed between the trees on clear days - a detail that Russell delighted in pointing out each time we made that drive. Past verdant plantations of green tea and indigo plants, across a red bridge stretching over a small but swift river, and up a final, challenging hill was our destination: a handsome century-old farmhouse and the site of my fieldwork.

I had been living in Japan for 18 months, although it was not until recently that I met Russell, through some serendipitous googling for local English-speaking textiles courses. It was a small dream of mine to study the craft of aizome (indigo dyeing) whilst in Japan. Russell's workshop, a ten-day crash course at his historic indigo farm, was an immediate hit. Furthermore, after several conversations and visits to Kamazawa, I became keen to establish this workshop as the site of my graduate fieldwork. I was curious to discover what attracted participants from around the world to these sold-out courses, and in doing so I hoped to achieve a better understanding of what made Japanese crafts so attractive to outsiders like myself. 
In the classic text, In Praise of Shadows, Junichiro Tanizaki famously states, "were it not for shadows, there would be no beauty" (200I: 46). A detailed image requires nuances in shadows and light, and so to with object writing. It is when these nuances are captured that the object gains social meaning. Writing about heritage crafts such as Japanese indigo textiles is an exercise in connecting the dots. What we think of as the "end product" is merely one point within a larger map, connecting to other points such as processes of making, notions of cultural identity, subjective concepts of creativity and craftsmanship, the phenomenology of landscapes, and so on. This holistic mindset is crucial to the field of design anthropology, which merges design practices with anthropological insight. In the piece "From Description to Correspondence: Anthropology in Real Time," proponents of design anthropology Tim Ingold and Caroline Gatt illustrate their criticisms of traditional ethnographic methods (Ingold \& Gatt 20I3). From their perspective, the anthropological tradition of participant observation has largely become a means for data collection, reducing knowledge gained through fieldwork to outside analysis "after the fact," to be filtered through an external set of theories. They propose a method of correspondence, stating, "to practice this method is not to describe the world or to represent it, but to open up our perception of what is going on there so that we, in turn, can respond to it" (2013: 6). This is similar to a popular term in the design industry known as "design thinking," which signals a shift from emphasizing form and function, to prioritizing user experience. Writing about objects within design anthropology is not so much about the objects themselves, but about the journey - the experience of making, creating, and using — or the phenomenology of objects. This framework also signifies a shift away from the visualism of anthropology, turning towards an emphasis on experience, process, knowledge, and meaning. By writing about processes of becoming rather than objects and end-results, we can achieve a better understanding of the phenomenon of experience.

Thus, my fieldwork in Japan represents an anthropology of correspondence. The following images capture moments in the field - experiences of places, people, objects, and processes of learning and making. Through this lens, I hope to achieve an anthropology not of design, but with design.

\section{REFERENCES}

Ingold,Tim and C. Gatt (2013) "From Description to Correspondence: Anthropology in RealTime". Pp. 139-I58 in W. Gunn et al. (ed.) Design Anthropology: Theory and Practice. London: Bloomsbury.

Tanizaki, J. (200I [1933]) In Praise of Shadows, translated by T.J. Harper and E.G. Seidensticker. New York:Vintage Books. 


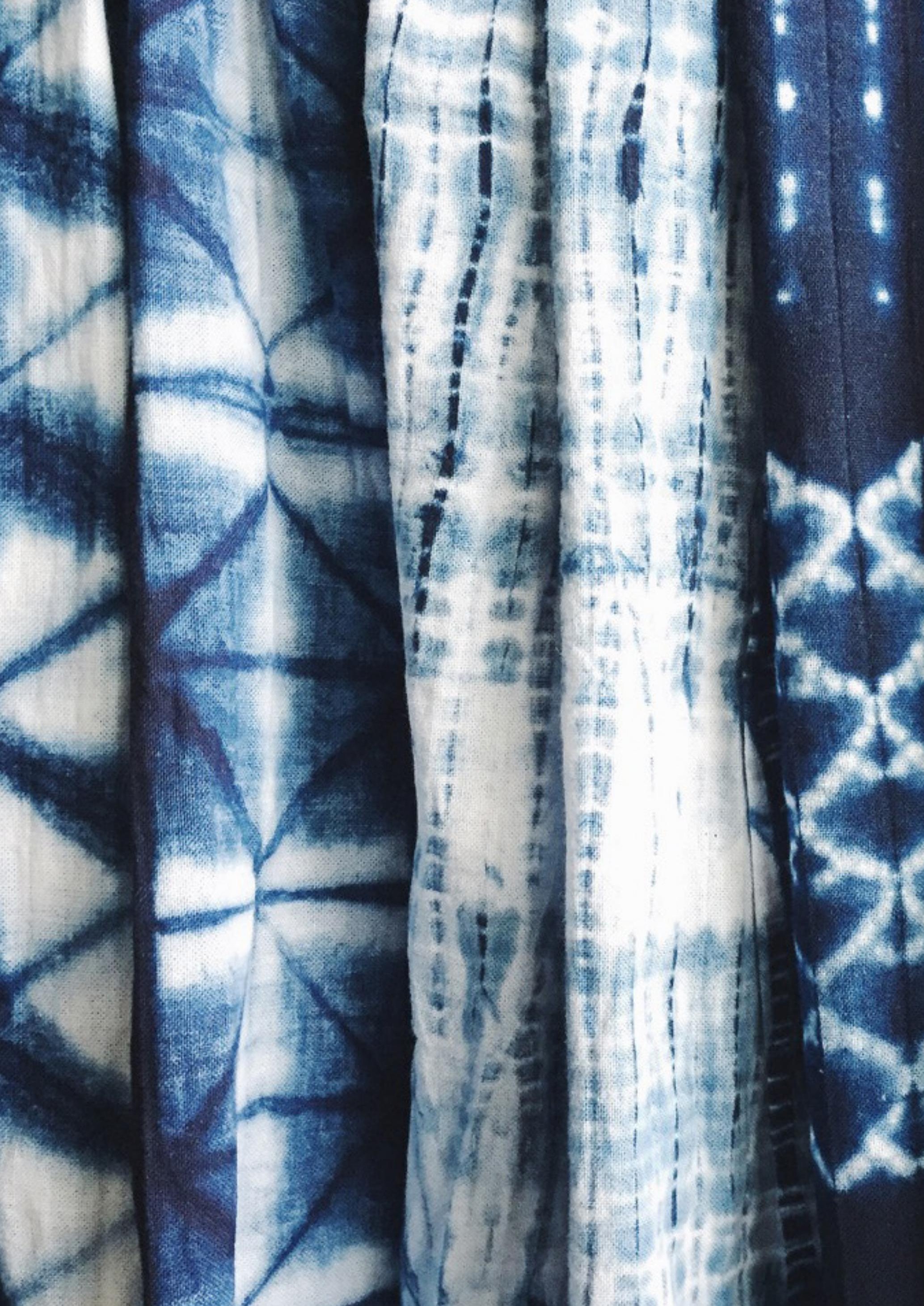

